\title{
Viral Marketing - The Case of Turkey
}

\author{
Hanna Lewicka, MSc \\ hanna.lewicka@ue.wroc.pl \\ Wrocław University of Economics \\ Department of Marketing Research \\ Wroclaw POLAND \\ $+48713680100$
}

Received: 21 August 2017/ Revised: 19 September 2017/ Accepted: 11 October 2017/Published online: 18 October 2017

\begin{abstract}
The purpose of this paper is to present and analyze successful viral marketing campaigns of Turkish advertisements in the form of a case study to determine which factors seem to play the most important role in terms of viral marketing message perception in Turkey. As a country in which the increasing role of digital media and the internet is beginning to dominate interpersonal communication, the use of viral approach in marketing is also growing. The examples of most viral videos in Turkey from the previous years confirm that the most important factor which determines the success of a viral message is its content, which should be at the same time attention-catching and entertaining. Nevertheless, the seeding strategy is the factor which accelerates the success of viral messages.
\end{abstract}

JEL classification: M31, M37.

Keywords: viral marketing, Turkey, advertising, digital media

\section{INTRODUCTION}

With the development of interactive media, consumers gain more control over how they are exposed to marketing messages and how they process them. They have the possibility to generate and spread information; therefore, they can also easily share marketing information if they want to do this. Because of that, marketing practitioners and advertising scholars have begun to explore how to use social network for marketing purposes (Soyoen et al., 2006, p. 100). The development of new media technologies, the dynamics behind it and the possibility of content sharing and content generation by its users led to the emerge of a new phenomenon called viral marketing.

Viral marketing can be defined as 'the phenomenon by which consumers mutually share and spread marketing- relevant information, initially sent out deliberately by marketers to stimulate and capitalize on word-of-mouth (WOM) behaviors' (Van der Lans et al., 2010, pp. 348-365, quoted in: Hinz et al., 2011, p. 55). Messages forwarded this way are usually unsolicited and forwarded to multiple recipients easily. Therefore, the viral marketing term's name has its roots in comparison to epidemiology (Hinz et al., 2011, p. 55). Like a flu or computer virus, it is spread by interpersonal contact (Soyoen et al., 2006, p. 100). Another definition says that viral advertising 'refers to marketer-initiated electronic-WOM (e-WOM) strategies that use specially crafted 
messages designed to be passed along or spread by consumers' (Porter and Golan, 2006, quoted in: Soyoen et al., 2014, p. 100).

The concept of viral marketing is not new, as the first viral campaign is said to emerge in 1996, launched by Hotmail. A promotional massage was attached to every e-mail which was sent via its service (Schulze et al., 2014, p. 1).

The most important benefits for companies which come from viral marketing implementation are (Schulze et al., 2014, p. 1; Hinz et al., 2011, p. 55; Dafonte-Gomez, 2014, p. 199):

- Customers' additional trust and attention, as the messages reach them from friends and other trusted sources;

- High control of the message content remaining;

- Ability to reach many consumers immediately - more than billions of connected customers are able to share marketing messages with a single click on their digital devices;

- Growing potential of social network platforms;

- Cost efficiency comparing to traditional media advertising, as the dispersion of messages is up to consumers;

- Time efficiency - one of viral campaigns conducted by Hotmail generated 12 million subscribers within 18 months, while viral advertisement triggered by Tipp-Ex ('A hunter shoots a bear!') reached almost 10 million clicks in 4 weeks;

- Free and engaging content masks its commercial purpose.

'Viral marketing has become a mainstream marketing instrument used by multinational firms in various industries' (Schulze et al., 2014, p. 1). Consumers, who more and more often consider themselves as being overwhelmed by advertisements, and mostly irrelevant ones, 'increasingly rely on advice from others in personal or professional networks when making purchase decisions' (Hinz et al., 2011, p. 55). Famous companies that utilized benefits which come from viral marketing include Unilever, Nike, Volkswagen and many more (Schulze et al., 2014, p. 1). However, there are also some limitations of viral marketing. These include (Hinz et al., 2011, p. 68):

- Cost for messages spreaders in terms of time invested and efforts made to capture their peers' attention;

- Lack of control over the spreading process.

There are four critical success factors of viral marketing which are said to be necessarily considered by companies (Hinz et al., 2011, pp. 55-56):

- Content and attractiveness of the message;

- The structure of social network;

- The characteristics of the message recipients in the behavioral context and their incentives for sharing the content;

- Seeding strategy.

The seeding strategy 'determines the initial set of targeted consumers chosen by the initiator of the viral marketing campaign' (Hinz et al., 2011, p. 56). Its importance comes from the fact that this factor is entirely under the control of the initiator - a company - and can influence significantly the viral campaign process. Also the social network is crucial in optimizing the seeding strategy, as it is easier to determine than the intensity, quality or frequency of communication. Because of that, examining social network and obtaining the information about it is a key thing for a viral marketing strategy (Hinz et al., 2011, p. 68). The message recipients' characteristics includes demographic profile, personality traits, and motivations that drive advertising sharing' (Sabri, 2015, p. 2).

The main aims of viral marketing campaigns are (Hinz et al., 2011, p. 59):

- Information spreading;

- Creating brand awareness; 
- Improving brand perception;

- Increasing sales as the effect of information exchange.

The first three aims stand for non-economic goals, and the last one constitutes an economic measure of success. Therefore, it can be said that viral marketing campaigns can serve both non-economic as well as economic reasons. Due to this fact, viral marketing campaigns can be divided into two groups - the ones in which 'social contagion mainly involves simple information transfers and results in greater awareness as a noneconomic measure of success' (Hinz et al., 2011, p. 59). In the campaigns of the second kind, 'social contagion relies on belief updating and results in sales' (Hinz et al., 2011, p. 59).

\section{THE PROCESS OF VIRAL MARKETING}

Viral marketing and word-of-mouth stand for similar ideas in marketing, but are not exactly the same. The main difference between them refers to the origin of the marketing message. In the word-of-mouth concept, consumers are the ones who create it and forward it to other people. In that way, the reactions of customers are strongly affected through the peripheral route, which means that they rely on social routes mainly. Therefore, the word-of-mouth gives the best results and benefits for utilitarian products' promotion (Schulze et al., 2014, p. 14).

By the definition, the word-of-mouth stands for 'a type of an informal channel of communication which involves direct (face-to-face) contact among individuals and groups concerning evaluations of goods and services' (Uslu et al., 2013, p. 458). The subject of the recommendation are corporations, products and brands. To make the word-of-mouth communication happen, these subjects should become a topic of an everyday conversation among people. However, nowadays, in the era of a growing role of digital communication, it can be said that not only direct conversation, in the face-to-face meaning, should be considered as the word-of-mouth, but any business-related recommendation which happens between at least two consumers.

However, for the receivers it is not always clear and obvious to distinguish which messages origin in their peers or are company-generated (Schulze et al., 2014, p. 14). In this context, viral marketing should be treated as a bigger entity and in this paper will be understood as sharing information both in firm-generated viral activities as well as the word-of-mouth.

There are three marketing variables when it comes to viral marketing - sender trust, advertiser trust and ad/message type. Choosing highly connected people as initial seeds of a viral marketing message gives a promise of a wider spread of it and reaching more consumers. Targeting such persons with specific marketing information may increase the success of a marketing campaign. Therefore, social relations, demographics and product characteristics are very important when making use of this marketing technique (Soyoen et al., 2006, p. 69). As Ch. Soyen, J. Huh and R. Faber claim, the trust towards the source of information distribution is also a key factor for viral advertising outcomes (Soyoen et al., 2006, p. 100). Also 'people tend to form trust in another person who is highly respected even when they do not know the person personally' (Soyoen et al., 2006, p. 102). The base of this trust is the belief that this person would not do something that could violate his or her reputation. This kind of trust can be called calculative, while the trust towards friends and family can be called a relational trust (Soyoen et al., 2006, p. 102).

Because it is related to the social network, the message distributor's characteristics are therefore also important for a viral marketing strategy. To achieve a maximal success, the distributor should be (Soyoen et al., 2006, p. 103):

- A person with good social relations,

- A person with connections,

- A trust sender for his peers. 
Messages which come from the advertiser directly are often viewed skeptically, as they are obviously intended to convince consumers to make a purchase. As the consumer's family members and friends 'are seen to have best interests at heart' (Soyoen et al., 2006, p. 100), they constitute better information providers, because of the importance of trust factor. It is important to distinguish trust from credibility, as trust 'focuses more on relational characteristics involving two parties interacting or forming relationships' (Soyoen et al., 2006, p. 102).

Figure 1

Viral marketing variables and four stages of advertising effect

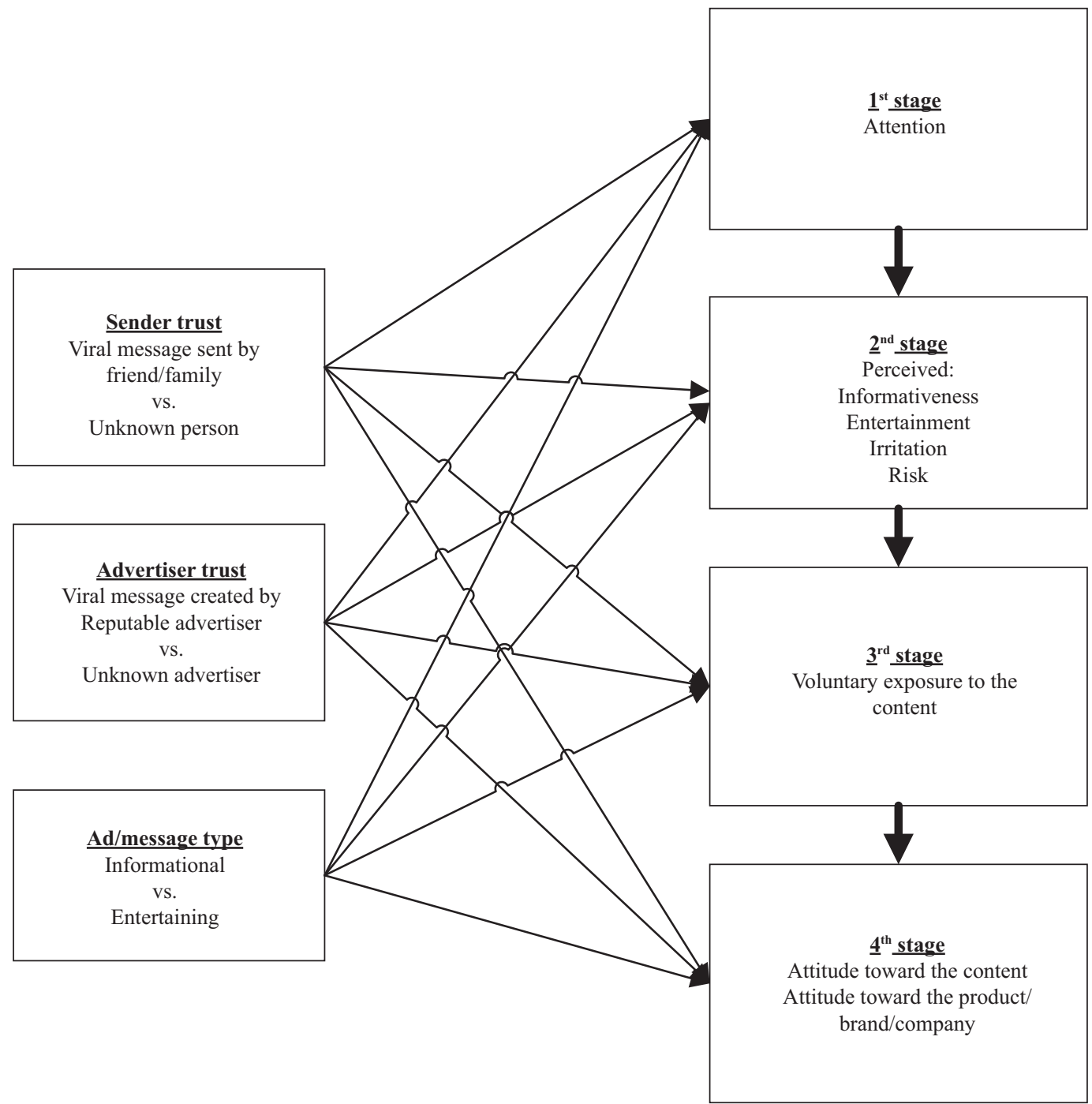

Source: Based on Soyoen, Ch., Huh, J., \& Faber, R. (2014). The influence of sender trust and advertiser trust on multistage effects of viral advertising. Journal of Advertising, 43, p. 101.

The range of advertising types in viral marketing encompasses visual and audio content, as well as videos, transmitted through social networks, social media, electronic mail and other platforms (Sabri, 2015, p. 1). Regarding the attractiveness of the message, according to the research made by A. Dafonte-Gomez, most shared viral video ads between 2006 and 2013 were characterized by 'a prominent presence of surprise and joy as dominant emotions' (Dafonte-Gomez, 2014, p. 199). O. Sabri also emphasizes that 'effective viral advertising needs to contain surprise and elicit higharousal emotional reactions, either positive or negative' (Sabri, 2015, p. 2).

Furthermore, the quality of the content determines taking the action of sharing it or not, as often the motivation of sharing comes from the need of constructing, expressing and projecting an individual's identity (Dafonte-Gomez, 2014, p. 201). 
Ch. Schulze, L. Scholer and B. Skiera emphasize that the viral marketing approach adopted for games on social media websites does not serve a successful promotion of products which are primarily utilitarian. As the researchers claim, the sharing mechanism suitable for entertainment application, like the one which has made FarmVille famous via Facebook, is the worst solution for promoting utilitarian merchandise (Schulze et al., 2014, p. 1). The reason for this is simply that what works for one type of product does not necessarily work for other kinds and just not all products are fun-oriented. One of classifications divides merchandise into utilitarian and hedonic categories. The most important traits of primarily utilitarian products are functionality, usefulness and practical aspects, whereas consumers who seek for primarily hedonic products look for their entertaining abilities (Schulze et al., 2014, p. 4).

In viral marketing, the message origin comes from companies and because of that it is more successful for less utilitarian products and products shown in a more informal and more entertaining way (Schulze et al., 2014, p. 14). Consumers who use social media do it with the intention of entertainment rather than looking for something useful. Therefore, as the social psychology says, their situational expectations when they visit a social platform do not correspond to viral marketing messages about utilitarian products (Schulze et al., 2014, p. 13). Seeking entertainment results in the fact that the consumers 'unconsciously devote fewer mental resources to evaluating actual message content and instead rely more on heuristics, simple inferences and social cues' (Schulze et al., 2014, p. 13). That is why processing information about low-utilitarian products is more successful.

In other words, it can be said that a product's campaign success using viral marketing solutions depends on choosing an appropriate sharing mechanism. For products which are characterized by more hedonistic traits, like music services, the sharing mechanism should involve recommendations made by friends rather than strangers and using incentives.

In general, durable goods, especially the ones which come from highly turbulent industries experiencing rapid changes, require a higher deal of involvement in the purchase decisions. Therefore, without doubts, electronic devices like mobile phones are products in the case of which the buying process, especially at the stage of choosing the model, takes longer time. So it can be expected that for this kind of merchandise more consumers will appreciate receiving a recommendation.

\section{DIGITAL MEDIA IN TURKEY}

As of $1^{\text {st }}$ January 2016, Turkey's estimated population in 2015 was 77,717,793 [1].

According to data collected by Internet World Stats, 46,282,850, which is $59.6 \%$ of the Turkish total population, were internet users (Table 1). Turks constitute $7.7 \%$ of internet users in Europe. A bigger penetration of internet users in Europe is noted only for France (9.2\%), Germany (11.9\%), the United Kingdom (9.8\%) and Russia (17.1\%) [1].

In 2015, 41,000,000 Turks were Facebook users (Table 1) [18]. Mobile phone use is very extensive in Turkey - in 2014, approximately $84 \%$ of Turkish people were active mobile subscribers [2].

Other data showed that in that in $2014,72 \%$ of Turkey's population were urban and $28 \%$ rural [2]. Because almost half of the country's land is given for agricultural purposes, while a majority of the population lives in modern urban environments like Istanbul and Ankara, E. Doğramac1 and D. Radcliffe call Turkey 'a country full of contrasts, in both the online - and offline world'. Meanwhile, it has the biggest youth population in Europe (16.6\% of the population in 2015 was aged 15-24, while Europe's average was 11.5\%); however, statistics also show that the population is ageing. Young people from Turkey's urban areas 'tend to be enthusiastic and proficient adopters of digital technology' [4]. 
The use of social media in Turkey is claimed to be possibly driven by a relatively low level of trust towards traditional media, as in $2015,45 \%$ of urban citizens 'stated that they do not think that they can trust most news most of the time' [4]. This statement cannot be generalized for the whole country; however, it offers 'an insight into the political polarization present across both the Turkish media and Turkish media consumers' [4].

Table 1

Digital statistics in Turkey (2015)

\begin{tabular}{lc|c} 
& Number & Penetration \\
\hline Internet users & $46,282,850$ & $59.6 \%$ \\
\hline Facebook users & $41,000,000$ & $52.8 \%$
\end{tabular}

Source: Internet World Stats, http://www.internetworldstats.com/euro/tr.htm, http://www.internetworldstats.com/stats4.htm\#europe.

The time spent by Turks on the internet via laptop/desktop in 2014 was $4 \mathrm{~h} 51 \mathrm{~m}$ daily on average. The average time spent on the internet through mobile phones was $1 \mathrm{~h} 53 \mathrm{~m}$, while the average time spent on social media reached $2 \mathrm{~h} 32 \mathrm{~m}$ (Table 2).

Table 2

Turkey - Average time spent on the internet each day (2014)

\begin{tabular}{lc}
\hline A desktop or laptop & $4 \mathrm{~h} 51 \mathrm{~m}$ \\
\hline Mobile phones & $1 \mathrm{~h} 53 \mathrm{~m}$ \\
\hline Average time spent on social media & $2 \mathrm{~h} 32 \mathrm{~m}$
\end{tabular}

Source: Global digital statistics, We Are Social - global conversation agency, 2014.

In $2014,44 \%$ of the Turkish population were social media users. It shows quite high potential for viral marketing (Table 3). Also $36 \%$ of the population were mobile internet users. What is more, among them $51 \%$ used social media applications on their mobile phone and $26 \%$ used location-based services [2].

Table 3

The penetration of chosen indicators as a percentage of the total population in 2014

\begin{tabular}{ll} 
Social media users & $44 \%$ \\
Mobile internet users & $36 \%$ \\
\hline Smartphone users & $95 \%$
\end{tabular}

Source: Global digital statistics, We Are Social - global conversation agency, 2014.

A very high percentage of smartphone users was observed $-95 \%$ of the population in 2014 . Among these users, 95\% searched for local information via their phone and 92\% searched for products in this way. A relatively high number of smartphone users had made a purchase via their phone $-43 \%$ [2]. However, the percentage of Turkish citizens who had access to mobile broadband in 2014 (36\% - Table 3) was relatively low. The social media use among internet users in Turkey is presented in Figure 2. 
Figure 2

Turkey - Social media use (among internet users)

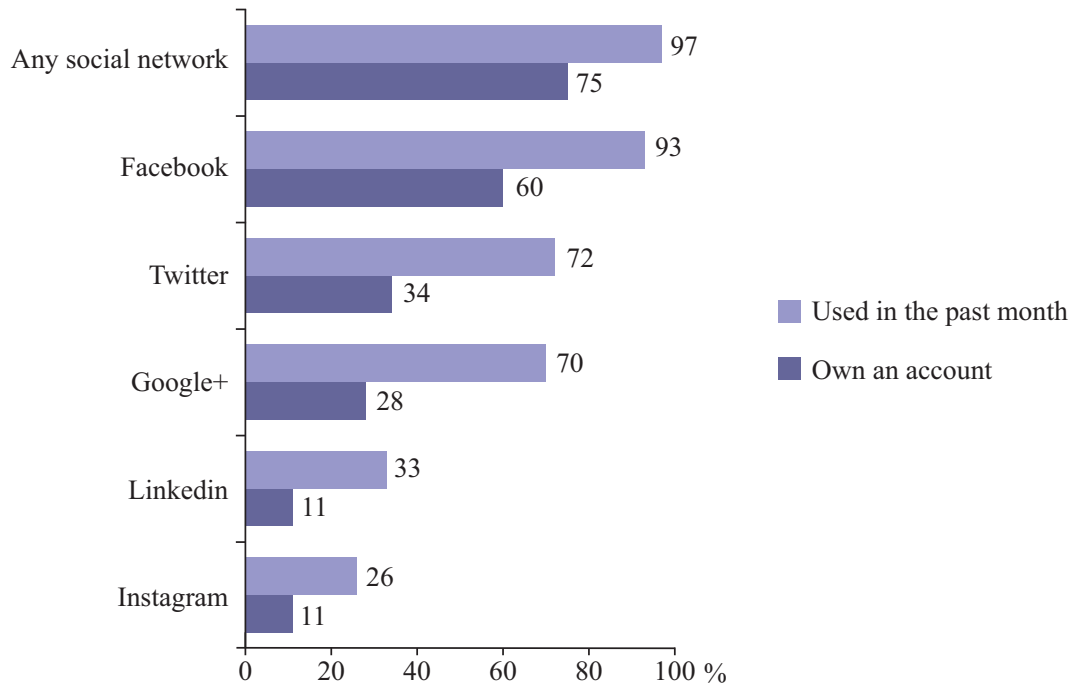

Source: Global digital statistics, We Are Social - global conversation agency, 2014.

The process of digitalization of the media in Turkey can be observed especially in the case of newspapers which have begun to feel the pressure of digital competition. Turkish Radikal even ceased to print its editions and decided to keep the online presence only [3]. The weekly percentage usage of top Turkish on-line journals is presented in Figure 3.

Figure 3

Weekly usage of the most popular Turkish on-line journals in 2015

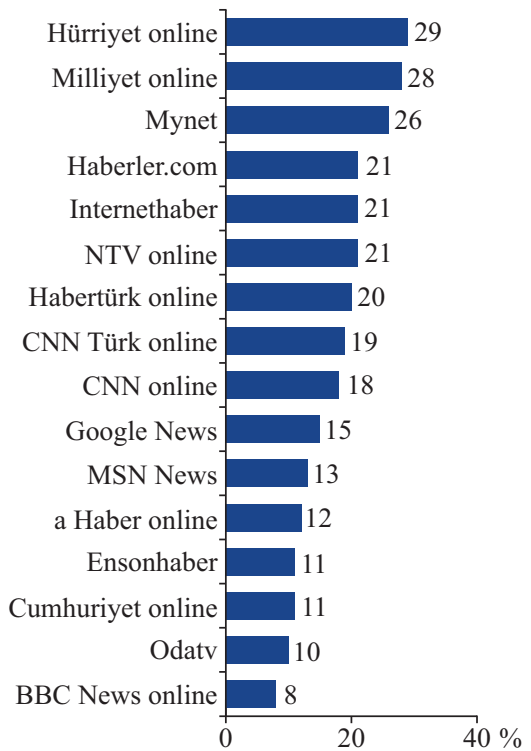

Source: Reuters Institute digital news report 2015 Supplementary report, Reuters Institute for the Study of Journalism, University of Oxford, 2015, p. 16.

Hurriyet.com is a website of one of the most established newspapers and together with Milliyet keeps the highest number of monthly online users. Newspapers in Turkey begun offering subscription packages, providing additional content for electronic editions designed for the tablet market, while still continuing to offer free access to the main part of their online content [3].

According to Reuters Institute Digital News Report 2015 Supplementary Report, 'Turkey has one of the world's highest Twitter penetration rates [3]. Based on research by GlobalWebIndex, in $201417 \%$ of Turks were Twitter users, and $87 \%$ of them were the citizens of Turkey's three 
largest cities - Istanbul, Ankara and Izmir [3]. It is one of the top countries in terms of Facebook popularity [3], being at the same time one of Facebook's fastest growing markets as well [3].

Social media are 'a group of Internet-based applications that build on the ideological and technological foundations of 2.0' (Kaplan \& Haenlein, 2010, pp. 59-68, quoted in: Ac1lar, 2015, pp. 96-97), which give free access to all kinds of information. They transform monologue into dialogue. Social media comprise tools and applications which allow 'individual and collective publishing, sharing of multimedia such as images, audio and video, and the creation and maintenance of online social networks' (Ac1lar, 2015, p. 97).

The popular uses of social media in Turkey include entertainment, lifestyle, sports and following famous personalities. Some of the most followed accounts on Twitter in Turkey are comedian Cem Y1lmaz, reaching the number of 9.94 million followers in 2015, and President Recep Tayyip Erdoğan - 7.1 million. What is worth mentioning is the popularity of Galatasaray Spor Kulübü - a football team which had 5.8 million followers on Twitter in 2015 [4]. What is interesting and important in terms of Turkish social media characteristics is that 'the only nonTurkish entry in the top 10 pages' (in 2015) 'for both Facebook and Twitter is the page for Dr Mehmet Öz' - a surgeoun and famous Turkish-American TV personality [4]. This expresses the importance of national values in Turkey, which cannot be forgotten by marketers interested in entering the Turkish market, and this should also be taken under consideration in implementing viral marketing campaigns.

Although the United States was ranked by Statista as the leading country based on the number of monthly active YouTube users (over 167 million) as of the 1st quarter of 2016 [5], Turkey was ranked as the first one considering the percentage of internet users in selected countries who watch online video content every day as of January 2017 (Figure 4).

Figure 4

Percentage of internet users in selected countries who watch online video content every day as of January 2017

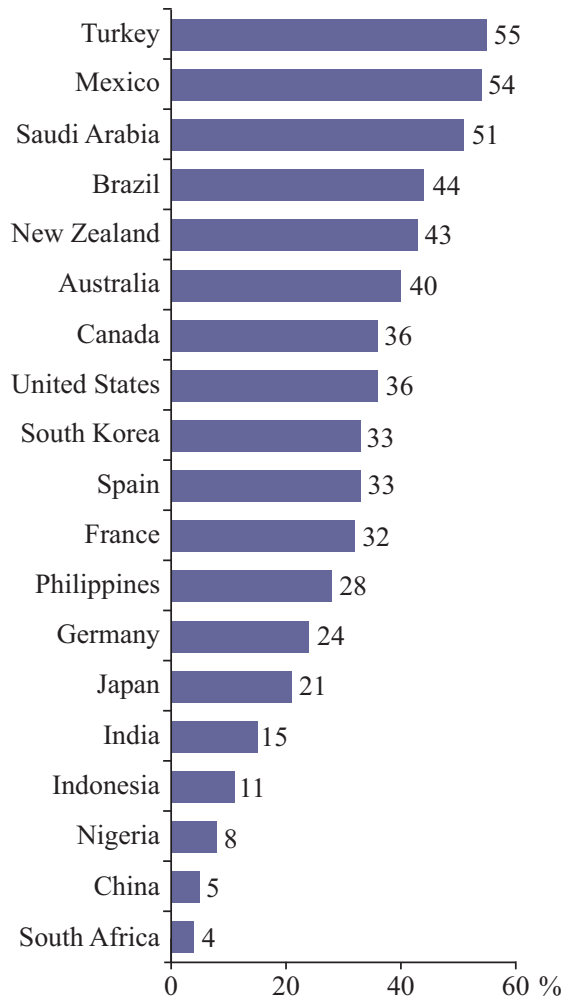

Source: Percentage of internet users in selected countries who watch online video content every day as of January 2017, Statista. The Statistics Portal, https://www.statista.com/statistics/319688/daily-online-video-usage/, 19.09.2017. 
According to these statistics, more than a half of internet users in Turkey watch online video content regularly, which confirms the potential of using the viral video concept as a marketing strategy in this country. Another fact that confirms it is that $94 \%$ of Turkish internet users watch online video content generally [6].

However, a growing influence of social media in Turkey caused unease amongst the Turkish authorities. From 2007 till 2015, eight different blocks on social media were noted. Especially prominent ones were temporary bans in 2014 and 2015 on Twitter and YouTube [4].

Twitter is considered to be 'a controversial but extremely popular social network in Turkey as it has been the tool for much political and social expression in recent years' [7].

Nevertheless, it had only a minor effect on internet users from Turkey among which many bypassed the restriction using tools like proxy servers or VPN (Azızlerl1, 2015, p. 37).

\section{VIRAL MARKETING IN TURKEY - A CASE STUDY}

Culture plays an important role in the decision making process. It determines the identity of human groups, shared meanings, language, laws, religion, traditions and customs (Uslu et al., 2013, p. 455). Each culture consists of many subcultures, and also each of them has their own, unique characteristics. Modern marketing discerns the importance of ethnical background and its influence on consumers' decisions, shopping habits, the impact of culture on consumers' approach towards brand loyalty, word of mouth and many more. Thus, there is no doubt about the influence of culture and national characteristics on viral marketing - how this phenomenon or concept is perceived, used and accepted or not, and how much popular it is.

Word-of-mouth seems to be one of Turkey's most important marketing factors. The results of the research conducted by A. Uslu, B. Durmuş and S. Taşdemir showed that the advice from friends and relatives regarding purchasing decisions was more important for Turks than for Germans, yet the difference was not significant. However, a significant difference was found regarding loyalty perception. The research, in which mobile phones were used as the subject of study, showed that Turkish consumers were less brand loyal than German consumers. Nevertheless, for evaluating the results of that research, it has to be emphasized that it was conducted on a Turkish minority group living in Germany. However, the difference regarding loyalty perception between German and Turkish consumers was observed for both high- and low-acculturated Turkish citizens (check: Uslu et al., 2013).

Nevertheless, as authors claim, in terms of viral marketing, 'the importance of social structure is beyond customer revenues and customer loyalty’ (Hinz et al., 2011, p. 68).

Examples of viral marketing messages may include information on occasional gift ideas, discount coupons, a link to entertaining videos and many more (Soyoen et al., 2006, p. 101).

Culture has especially big importance in terms of choosing the content of a viral marketing message. For example, according to Porter and Golan's research, 'sex, violence and nudity-related content - generally enveloped by an air of comedy - gets better results in terms of dissemination by users' (Dafonte-Gomez, 2014, p. 201). There are taboos which are common to most of the countries; however, some content may be more controversial in particular cultures. Using the same advertising message can cause different reactions in various societies. According to D. Waller, K. Fam and B. Erdogan's research, gambling, religious denomination, racially extremist groups as well as gun and armaments containing content seem to be offensive (Waller et al., 2005, p. 9). Furthermore, as an important cultural issue, it should not be forgotten that alcohol and cigarettes advertising, sponsorship and promotion are banned in Turkey (Bilir et al., 2009, p. 2). Underwear and contraceptives advertisements as well as sexual disease prevention and weight loss programs also might be slightly controversy-causing topics (Waller et al., 2005, p. 9). On the other hand, further research regarding this topic is needed as Turkey seems to have an internally differentiated 
society. However, this fact is commonly not taken under consideration in recent surveys in which the Turkish society is considered as a very socially unitary country.

As O. Sabri claims, according to research results, taboo in viral advertising 'does not develop a more positive attitude toward the sponsored brand and more positive intentions to purchase the product depicted in the advertisement' (Sabri, 2015, p. 3). What is more, it violates subjective norms which 'indicate how individuals rely on the judgment of significant others and members of their community when deciding to perform a specific behavior' (Sabri, 2015, p. 4). Therefore, then the advertisement is perceived by individuals as controversial, it can discourage them from buying the promoted product, as they tend to think that other people will not approve of that (Sabri, 2015, p. 4).

Therefore, controversial viral advertising, a hazardous marketing strategy itself, seems to be especially risky in Turkey, considering the collectivistic nature of its society, as G. Hofstede classified it [8].

In this paper, three Turkish advertisements will be analyzed, using a case study research method. The advertisements will be examined based on their content, number of views of the videos and the possible factors which made them become viral.

On the Cannes to Cannes Lions 2014 Leaderboard, which is a list of ten most viral advertisements on YouTube, two Turkish advertisements found place in the ranking [9]:

1. Turkish Airlines "Kobe vs. Messi: The Selfie Shootout"

2. YouTube "Rewind: What does 2013 Say?"

3. Wren "First Kiss"

4. Volvo Trucks "Epic Split featuring Jean Claude Van Damme"

5. Budweiser "Puppy Love Super Bowl Ad"

6. Nike Football "Winner Stays featuring Cristiano Ronaldo"

7. Pantene Philippines "Labels Against Women"

8. Google "Google Zeitgeist: Here's to 2013"

9. Save the Children UK "Most Shocking Second-A-Day Video"

10. Cornetto Turkey "Yalın - Keyfi Yolunda, Aşkı Sonunda"

Turkish Airlines' 'Kobe v Messi: The Selfie Shootout' reached the top of the ranking, with more than 137.4 million views at the time when the clips were judged. In the advertisement, created by Crispin Porter + Bogusky, Messi and Kobe race across the world in order to find the best places to take selfie photos and to access most places worldwide, traveling with Turkish Airlines (Figure 5) [10].

\section{Figure 5}

The idea of Turkish Airlines viral video with Kobe and Messi

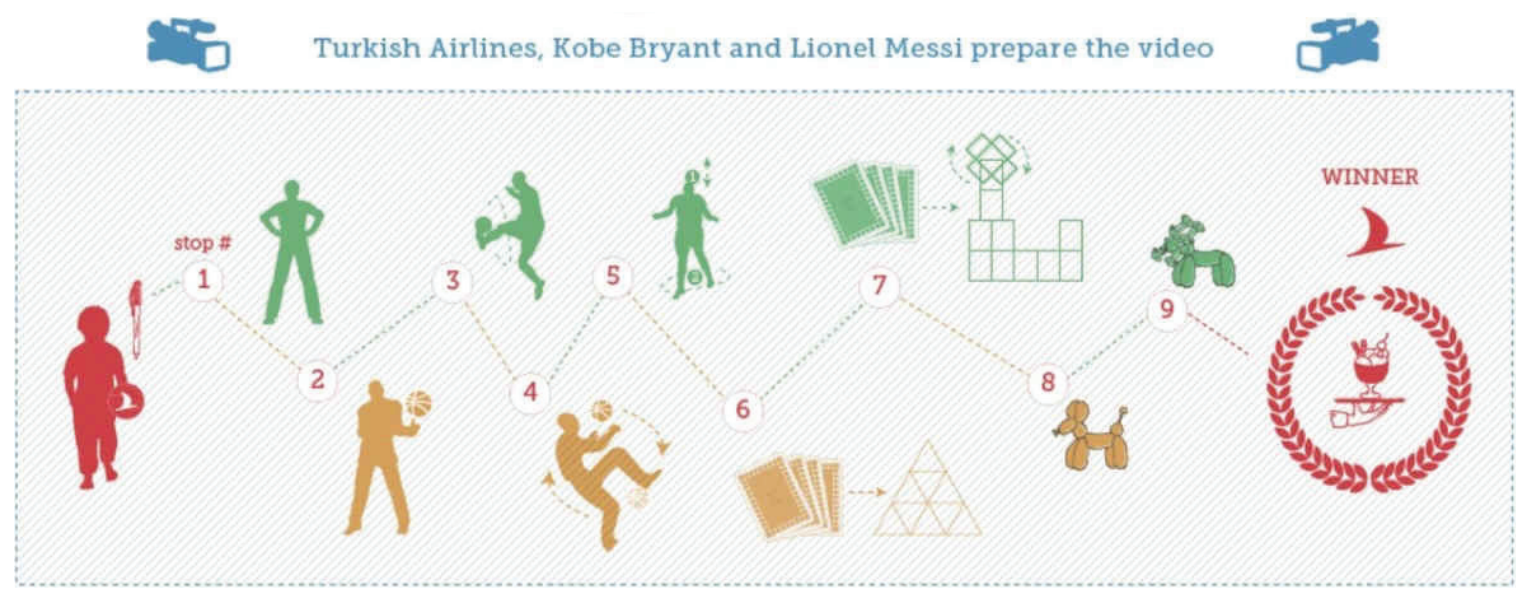

Source: Laird, S. How that Turkish Airlines 'Kobe vs. Messi' ad went super viral, http://mashable.com/2013/04/10/turkish-airlines-kobe-messiviral-ad/\#6qa6CgFa7kqy, 10.04.2013. 
The company's aim was to emphasize the global network of the airline, as 'the competitive athletes are seen at various airports consulting the airline's destination boards for their flights' [11]. The video was based on the idea of three successful stars meeting: Kobe, Messi and Turkish Airlines. Two celebrities in a celebrity - worth place, an airline which flies to 'more countries than any other airline' [12]. The video went viral immediately. In just four days, it reached the number of views which famous music clip 'Gangnam Style' by Psy had reached in 30 days [12]. Currently (08.05.16), it exceeded over 144 million views on YouTube.

However, as S. Laird claims, the success of the video was not based on a good advertising message solely. It is said that the video seeding was supported by Plaid Social Lab online advertising company, which increased its success by 'identifying high-profile YouTube users, then convincing and paying those users to casually share the ad with their large and dedicated online followings after it was uploaded (...) Then a lot of other people see the video through them, and they end up sharing it for free' [13]. As the founder of the company, Ricky Ray Butler, said, if the video had the potential to go viral, it would have gone viral anyway, however, the support accelerated it and helped it reach such an incredible number of views [13].

Figure 6

The success of the Turkish Airlines video vs Gangnam Style music clip's success

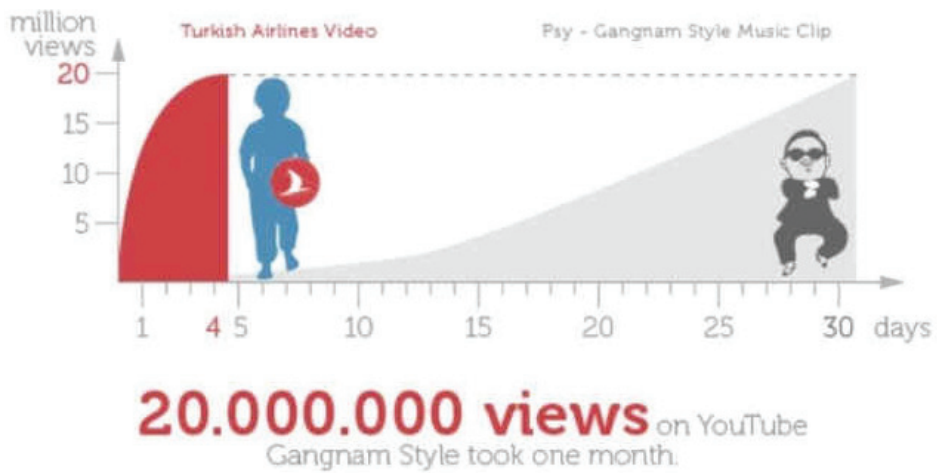

Source: Laird S., How that Turkish Airlines 'Kobe vs. Messi' ad went super viral, http://mashable.com/2013/04/10/turkish-airlines-kobe-messiviral-ad/\#6qa6CgFa7kqy, 10.04.2013.

The meaning and the message of an advertising is 'conveyed by the link between the attributes associated with the people in the advertisement and the relationship they embody between themselves and the product' (Leiss et al., 2005, p. 184). For that reason, to discover the advertising message it is important to analyze these elements.

\section{Figure 7}

Turkish Airlines: 'Kobe vs. Messi: The Selfie Shootout' advertising message - screen shot 1

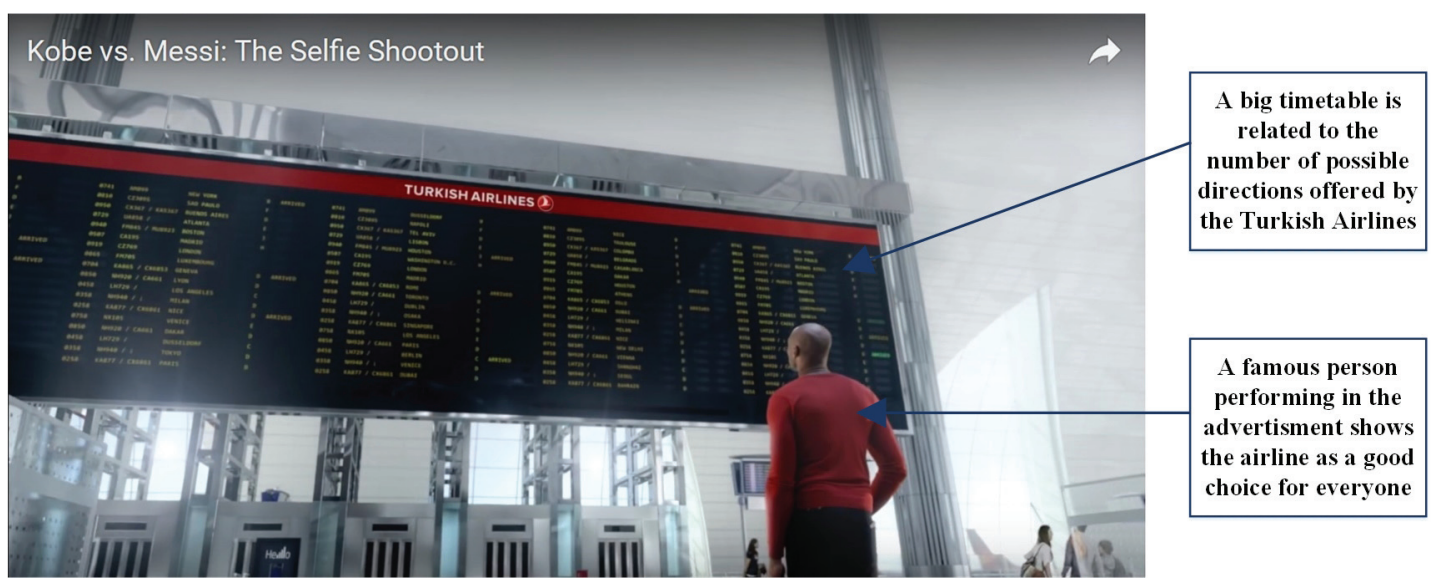

Source: Own elaboration, https://www.youtube.com/watch?v=jhFqSlvbKAM. 
The advertisement begins with Messi challenging Kobe by sending him a selfie from Moscow. Kobe, while thinking of how to beat that, chooses among the destinations offered by the Turkish Airlines. This implies that Turkish Airlines has the widest choice available, considering that such a well-known person as Kobe chooses this airline, not another, to beat Messi. It corresponds to the final slogan and the main idea of the advertisement: 'Flying to more countries than any other airline.'

The origins of persons shown in the advertisement underline the global character of the company. Showing people of different races as flight attendants implies that the airline serves all kinds of passengers from all over the world, without any borders. On the other hand, the competition between Kobe and Messi can be also interpreted as a war between people of different races too.

\section{Figure 8}

Turkish Airlines: 'Kobe vs. Messi: The Selfie Shootout' advertising message - screen shot 2

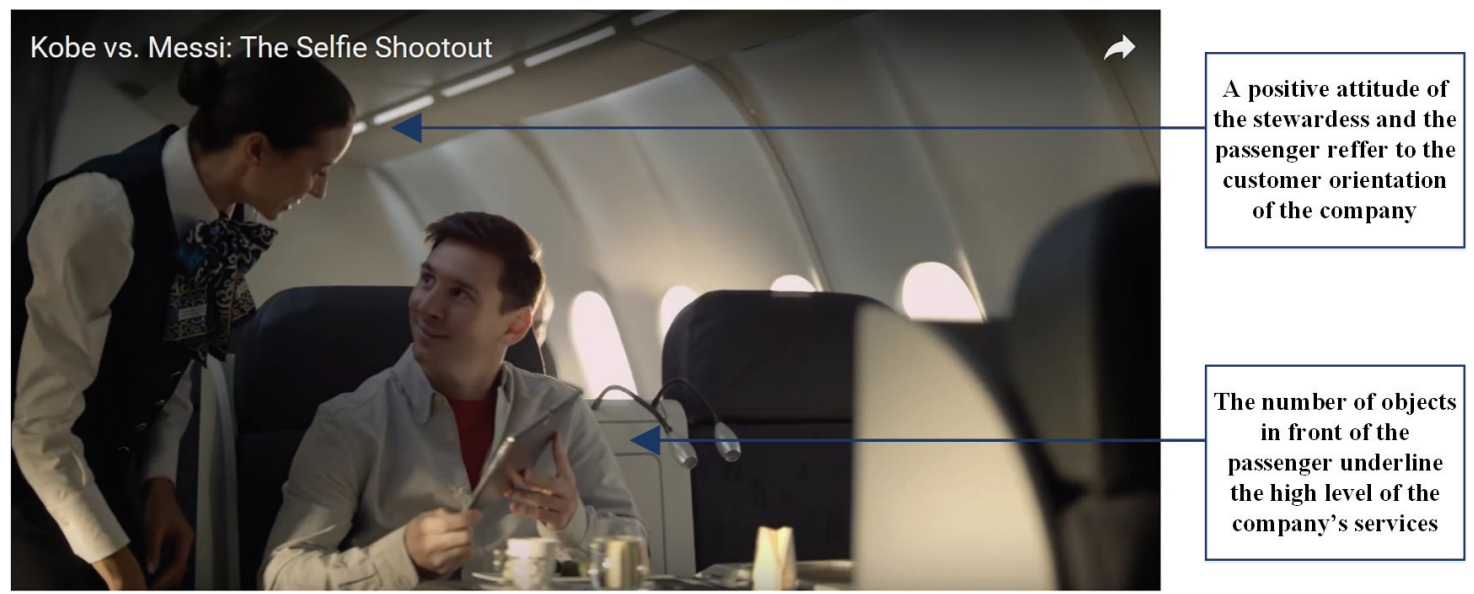

Source: Own elaboration, https://www.youtube.com/watch?v=jhFqSlvbKAM.

In another Turkish Airlines advertisement, involving the same celebrities, 'Kobe vs Messi: Legends on board', 'Bryant's acts seem to display lower levels of difficulty' [15], hence they were suspected to show some discrimination or prejudice against Afro-American people. However, considering that the presented relation between the characters was definitely friendly and the competition in which they were taking part looked more comedic than serious, this way of perception seems to be some kind of misinterpretation. In this advertisement, both of the celebrities, while trying to impress a young boy by their skills and tricks, in the end fail against a stewardess offering him some ice cream. It humanizes the image of the airline and underlines its customer-oriented attitude in business.

The idea regarding which character is more successful in the advertisement seems to be more a result of who began the challenge. In the 'Kobe vs. Messi: The Selfie Shootout', Kobe is presented to be as the more successful one - he poses with a shark and then with a lion, while Messi poses with some less dangerous fish and a monkey. It implies that Kobe's ideas were more dangerous, and therefore, more impressive. Considering this, it rather can be said that Turkish Airlines advertisements show the equality of people who come from different cultures and have competitive professions (here: football and basketball) and who can be united when it comes to different activities, and especially travelling.

The plot of the advertisement shows the chain of events in which the main characters come with more and more impressive and creative ideas with each photo shot - starting from a usual selfie, going through more and more challenging activities. In the end, both of them come to Istanbul, representing it as the most impressive place to take a selfie, referring to Turkish national values and underlining the roots of the company being its additional benefit. 
Figure 9

Turkish Airlines: 'Kobe vs. Messi: The Selfie Shootout' advertising message - screen shot 3

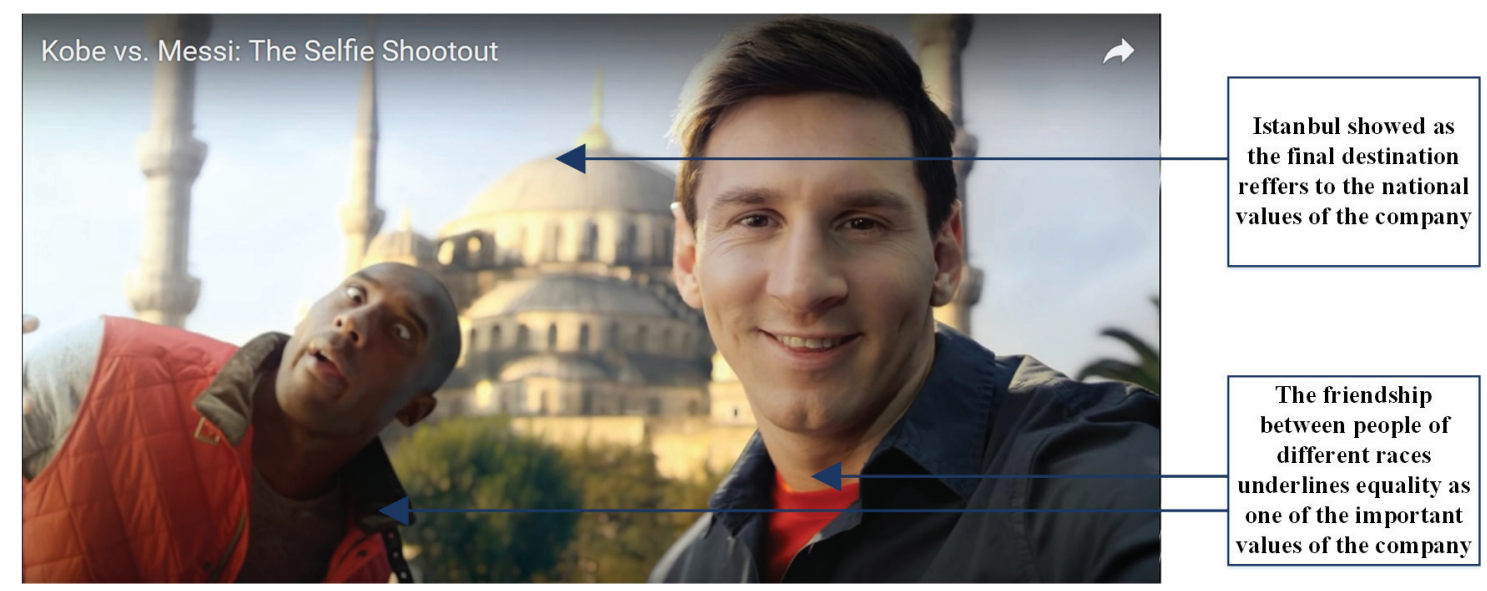

Source: Own elaboration, https://www.youtube.com/watch?v=jhFqSlvbKAM.

The second Turkish advertisement closed the list, finding its place on number ten. The advertisement is a video of 'a short romance of two teenagers pursuing Parisian love, set to the music of pop singer Yalın' [16]. Cornetto's advertisement "Yalın - Keyfi Yolunda, Aşkı Sonunda" (created by MOFILM agency) is a proof of how good and compelling stories can cross language barriers and become viral globally. In the video, there is no appearance of ice cream. The advertisement reached around 2.4 million shares and 27.1 million views in 2013 [14].

Figure 10

Cornetto Turkey 'Yalın - Keyfi Yolunda, Aşkı Sonunda'- screen shot 1

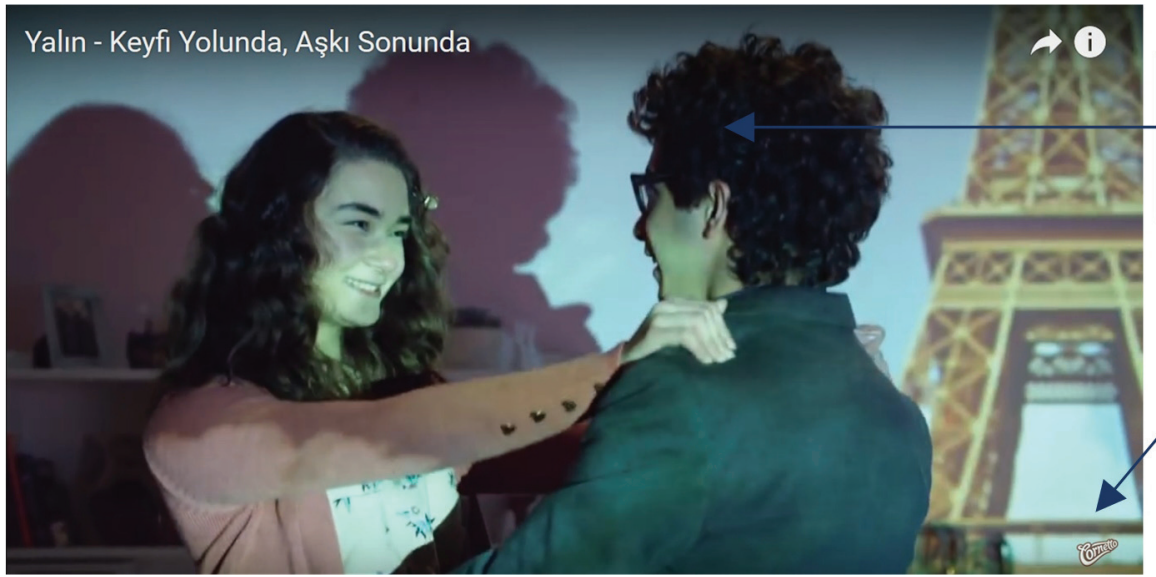

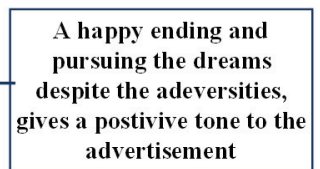
advertisement

The product (ice cream) does not appear during the whole advertisement. However, a small logo is visible all the time in the corner.

Source: Own elaboration, https://www.youtube.com/watch?v=xEb87JQ9CKQ

In Cornetto's video, the advertised product - ice cream - does not appear even once. Only a little logo is visible all the time in the corner of the video. Cornetto's whole campaign is based on the idea of presenting some short love stories. It is a good example of how to get some audience without a strident brand exposure. In fact, while watching this kind of videos, people are interested in the story, not in the advertised product, but that makes them remember the brand - where the video comes from - and it helps to build brand awareness. 
Figure 11

Cornetto Turkey 'Yalın - Keyfi Yolunda, Aşk1 Sonunda'- screen shot 2

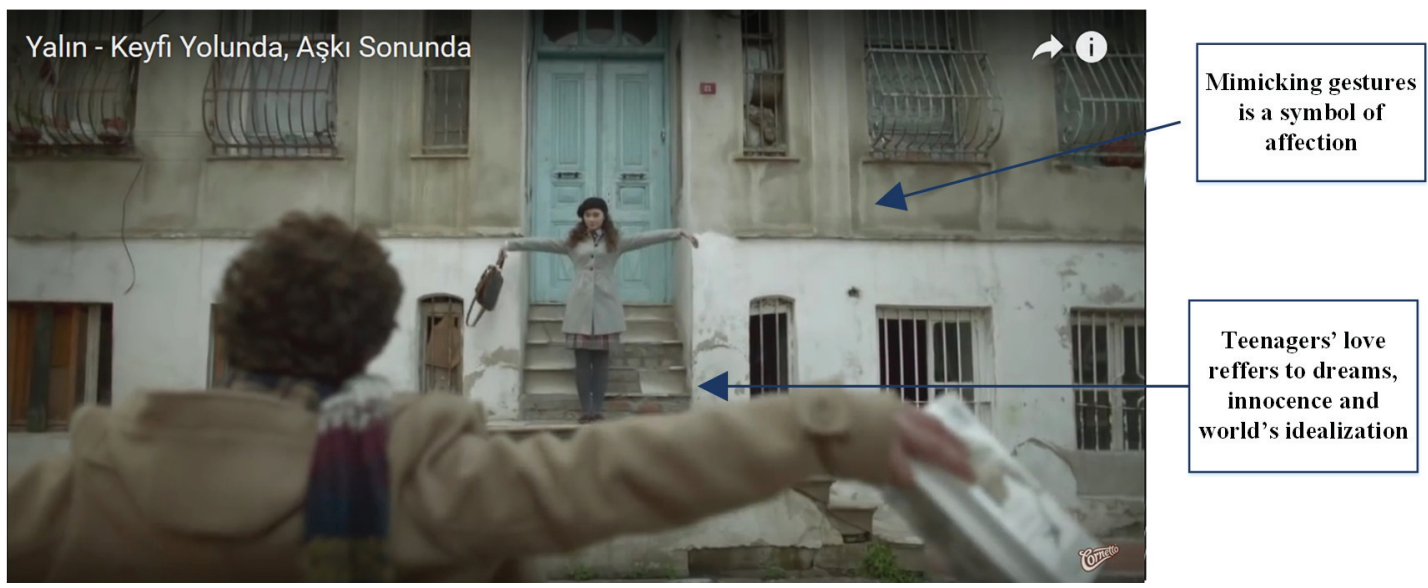

Source: Own elaboration, https://www.youtube.com/watch?v=xEb87JQ9CKQ

Another interesting message which became viral in Turkey is 'Eski sevgilime kapak olsun' video released by GittiGidiyor.com, 'the most widely-used e-shopping mall in Turkey with more than 7 million registered users, over 500 thousand daily visitors and 4 million listings at any given time'. GittiGidiyor.com is a part of eBay [17]. To gain consumers' attention, the company created an outstanding video in which a young girl named Fulya Timut talks about the personal objects which she planned to sell on GittiGidiyor.com and which are related to her past relationship. The place where the recording was made and the general quality of the voice imitated amateur recording, making the video look more casual and less commercial. It gives the impression of a video posted by a random, not business-related, person.

The girl who takes part in the video shows objects (in good state and also some expensive ones like a camera) which used to be important to her. She explains why, and also why they are not important for her anymore and why she wants to sell them. The objects presented in the video, which were marked with the code 'Intikam' (ang. Revenge), were sold within five hours [18].

The viral campaign increased the awareness of the website. The video reached the number of 4.7 million views just in one month after releasing it. 134 thousand people used the 'Intikam' keyword to find the objects posted for sale by the person starring in the video. The Facebook account created for Fulya Timur was offered a friendship by 60 thousand people within 24 hours [19].

All of the above show some examples of videos in which a well-designed content and a good seeding strategy led to successful viral marketing campaigns in Turkey. Based on that, it can be supposed that these two factors play the most important role in terms of viral marketing perception in Turkey. 
Figure 12

GittiGidiyor.com - 'Fulya'nın İntikamı' - screen shot

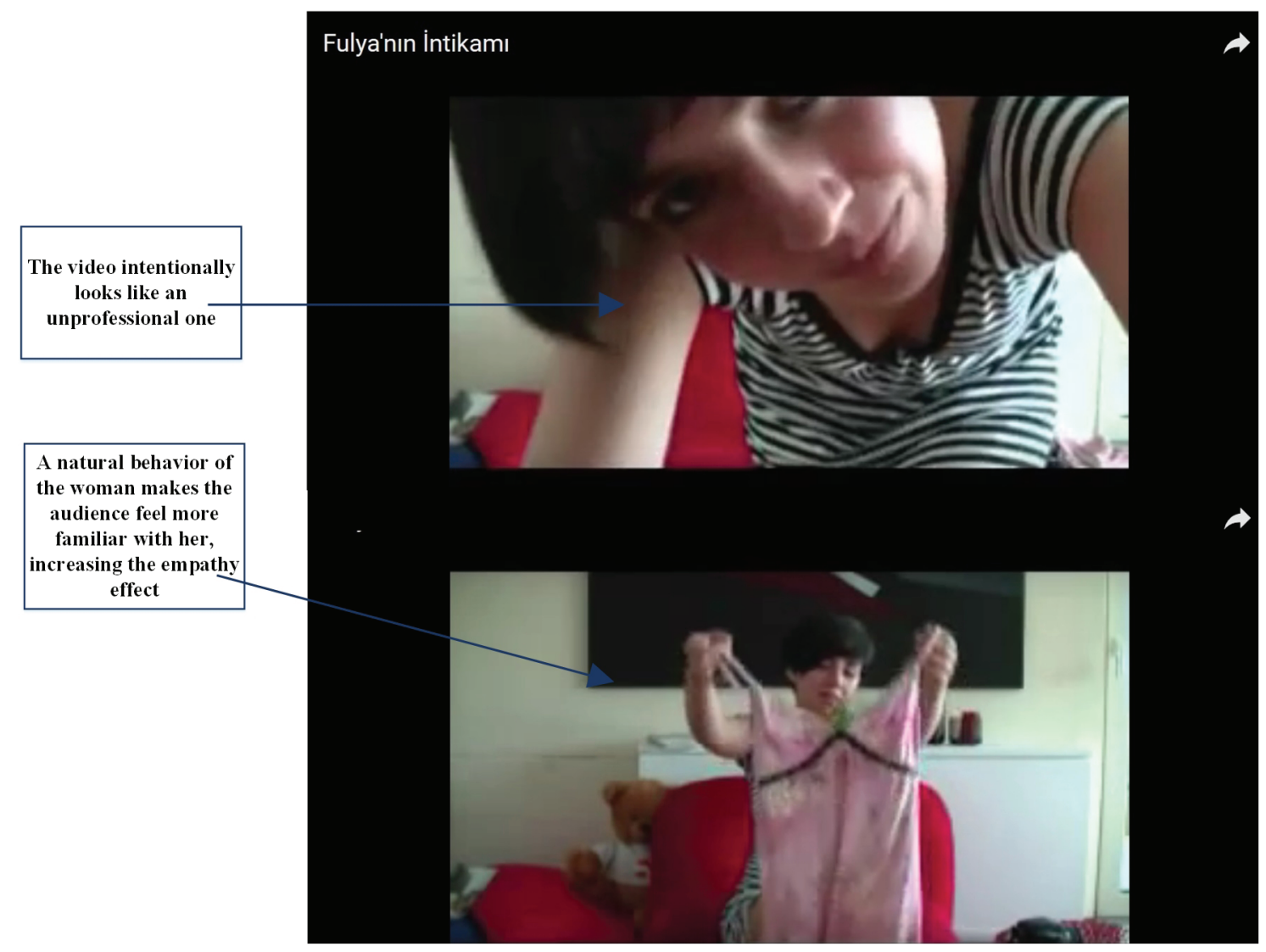

Source: Own elaboration, https://www.youtube.com/watch?v=O48A8u3aano.

The number of views of a particular video is the first and important indicator of the success of a marketing campaign. However, it is important to remember that at the same time the broadcast is only a small part of a marketing strategy and that the ultimate success of it cannot be judged by high advertising exposure solely.

In 'Viral Marketing in the Internet. Characteristics of an Effective Virus', Kwiatkowska mentions some methods which allow the effectiveness of viral marketing to be measured ${ }^{1}$ :

- Cost Through Rate parameter (CTR) - a number of clicks on the advertisement in relation to its general display. In other words, CTR shows the percentage of people who visited the website after seeing the advertisement.

- Return of Investment parameter (ROI) - the return of the costs of the placement of a viral message on the Internet. The disadvantage of this parameter is the inability to determine clearly which of marketing activities affected product's sales, especially if there was a parallel advertising campaign through other media.

To estimate the real success of the advertisements mentioned in this paper would require a further investigation, including the changes in sales or at least the number of people who visited the product's website because of the campaign. Due to the limited data, in this paper only the most evident result of the advertising campaign has been presented, which is a high number of views of the videos, obtained by a proper design of the content of the videos and a good planning of the sharing strategy.

Kwiatkowska, J.A. (2009). Viral marketing in the internet. Characteristics of an effective virus. Annales Universitatis Apulensis Series Oeconomica, 11(2), 1050-1052. 


\section{SUMMARY}

The idea of viral marketing and the word-of-mouth communication is commonly based on the idea of fast forwarding an accurate message to customers, or enhancing the value of random information by the fact that it has been forwarded or recommended by a trustworthy person like a friend or relative. However, the effectiveness of viral marketing depends on many factors and messages require various sharing strategies according to their content and the characteristics of the group which they are supposed to target. Considering this fact, viral marketing cannot be evaluated as a simple marketing tool which will work in any kind of business communication. Companies should see it as a new and powerful tool which enables a wide group of potential customers to be reached in seconds. Nevertheless, to benefit from the viral marketing technique, it is necessary to understand both its limits and its potential, in order to make use of it in the best possible way, correctly adjusted to each kind of marketing message and product, taking into account the target country's cultural characteristics. Turkey as a country in which the increasing role of digital media and the internet is beginning to dominate interpersonal communication, the use of viral approach in marketing is also growing. This increasing role of digital media in communication in Turkey created an environment in which messages can be spread fast to huge amount of consumers in seconds. The examples of the most viral videos in Turkey from previous years confirm that the most important factor which determines the success of a viral message is its content, which has to be at the same time attention-catching and entertaining. Nevertheless, the seeding strategy is the factor which accelerates the success of viral messages.

\section{References}

Acilar, A. (2015). The use of social media in the higher education institutions in Turkey: A case of the higher education institutions in Istanbul. In: A. Khanları (Ed.), Strategic customer relationship management in the age of social media. IGI Global.

Azızlerl1, E. (2015). Reuters Institute Digital News Report 2015 Supplementary Report. Reuters Institute for the Study of Journalism, University of Oxford.

Bilir, N., Cakir, B., Dagli, E., Erguder, T., \& Onder, Z. (2009). Tobacco control in Turkey. WHO.

Dafonte-Gomez, A. (2014). The key elements of viral advertising. From motivation to emotion in the most shared videos. Media Education Research Journal, 43.

Hinz, O., Skiera, B., Barrot, Ch., \& Becker, J. (2011). Seeding strategies for viral marketing: An empirical comparison. Journal of Marketing, 75.

Kaplan, A. \& Haenlein, M. (2010). Users of the world, unite! The challenges and opportunities of social media. Business Horizons, 53.

Kwiatkowska, J. A. (2009). Viral marketing in the internet. Characteristics of an effective virus. Annales Universitatis Apulensis Series Oeconomica, 11(2).

Leiss, W., Kline, S., Jhally, S., \& Botterill, J. (2005). Social communication in advertising: Consumption in the mediated marketplace ( $3^{\text {rd }}$ edition). New York: Routledge.

Porter, L. \& Golan, G. (2006). From subservient chickens to brawny men: A comparison of viral advertising to television advertising. Journal of Interactive Advertising, 6.

Reuters Institute for the Study of Journalism. (2015). Reuters Institute digital news report 2015 Supplementary report. University of Oxford.

Sabri, O. (2015). Does viral communication context increase the harmfulness of controversial taboo advertising?. Journal of Business Ethics.

Schulze, Ch., Scholer, L., \& Skiera, B. (2014). Not all fun and games: Viral marketing for utilitarian products. Journal of Marketing, 78, January.

Soyoen, Ch., Huh, J., \& Faber, R. (2014). The influence of sender trust and advertiser trust on multistage effects of viral advertising. Journal of Advertising, 43.

Turkish Airlines. (2014). Turkish Airlines wins most viral celebrity spot at Advertising Age's 2014 Viral Video Awards. Business Wire.

Uslu, A., Durmuş, B., \& Taşdemir, S. (2013). Word of mouth, brand loyalty, acculturation and the Turkish ethnic minority group in Germany. Procedia - Social and Behavioral Sciences, 99. 
Van der Lans, R., Van Bruggen, G., Eliashberg, J., \& Wierenga, B. (2010). A viral branching model for predicting the spread of electronic word-of-mouth. Marketing Science, 29.

Waller, D., Fam, K., \& Erdogan B. (2005). Advertising of controversial products: a cross-cultural study. Journal of Consumer Marketing, 22(1).

[1] Population of Turkey 2015, Turkey population clock, http://countrymeters.info/en/Turkey, 27.03.16.

[2] We Are Social - global conversation agency (2014). Global digital statistics, http://etonpreneurs.com/uploads/ Global\%20Social,\%20Digital\%20\&\%20Mobile\%20Statistics,\%20Jan\%202014.pdf, 26.03.16.

[3] Reuters Institute for the Study of Journalism. (2015). Reuters Institute digital news report 2015 Supplementary report (p. 36). University of Oxford.

[4] Doğramac1, E. \& Radcliffe, D. How Turkey uses social media. Reuters Institute for the Study of Journalism, University of Oxford, http://www.digitalnewsreport.org/essays/2015/how-turkey-uses-social-media/, 27.03.16.

[5] Leading countries based on number of monthly active YouTube users as of 1st quarter 2016 (in millions). Statista. The Statistics Portal, https://www.statista.com/statistics/280685/number-of-monthly-uniqueyoutube-users/, 19.09.2017.

[6] Percentage of internet users who watch online video content on any device as of January 2017 by country. Statista. The Statistics Portal, https://www.statista.com/statistics/319688/daily-online-video-usage/, 19.09.2017.

[7] Social media guide for Turkey: Main social media networks, (C) 2014 Passport to Trade 2.0, Life Long Learning Programme, http://businessculture.org/southern-europe/business-culture-in-turkey/social-mediaguide-for-turkey/, 15.04.16.

[8] The Hofstede Centre, http://geert-hofstede.com/turkey.html, 13.02.16.

[9] THY, YouTube'un zirvesine yerleşti!, Marketing Türkiye, 2014, http://www.marketingturkiye.com.tr/haber/ thy-youtubeun-zirvesine-yerlesti, 18.04.16.

[10] Sullivan, L. (2014). Google's YouTube releases Cannes To Cannes Lions 2014 Leaderboard. MediaPost, June, http://www.mediapost.com/publications/article/227560/googles-youtube-releases-cannes-to-canneslions-2.html, 18.04.16.

[11] Turkish Airlines. (2014). Turkish Airlines wins most viral celebrity spot at Advertising Age's 2014 Viral Video Awards. Business Wire.

[12] Laird, S. How that Turkish Airlines 'Kobe vs. Messi' ad went super viral, http://mashable.com/2013/04/10/ turkish-airlines-kobe-messi-viral-ad/\#6qa6CgFa7kqy, 10.04.2013.

[13] Laird, S. Kobe and Messi: How viral marketing sausage is made, http://mashable.com/2013/12/09/kobemessi-ad-seeding/\#BikBe8.kgiqD, 10.12.2013.

[14] Kubiak, K. (2013). Reklama outdoroowa - semiotyczna analiza przekazu. In: A. Wiśniewska \& A. Frontczak, Reklama wizualna (p. 8). Warszawa: Wyższa Szkoła Promocji, http://www.wsp.pl/file/1217_26819627.pdf.

[15] Response to Sharon's analysis of Turkish Airlines advertisement. Prof. Portwood-Stacer's course at NYU, Advertising \& Society, 2013, https://advsoc2013.wordpress.com/2013/04/09/response-to-sharons-analysisof-turkish-airlines-advertisement/, 08.05.16.

[16] Ueland, S. (2013). 12 most-shared video ads of 2013. Practical Ecommerce (December), http://www. practicalecommerce.com/articles/62413-12-Most-shared-Video-Ads-of-2013, 18.04.16.

[17] http://yardim.gittigidiyor.com/yeni-uyeler/about-gittigidiyor, 23.04.16.

[18] Aldatılan kızın müthiş intikamı, http://www.cumhuriyet.com.tr/haber/diger/76274/Aldatilan_kizin_muthis_ intikami.html, 23.04.16.

[17] Başusta, H. Röportaj: GittiGidiyor'un Eski Sevgiliye Kapak Viralinin Ayrıntıları, http://webrazzi. com/2009/10/22/roportaj-gittigidiyorun-eski-sevgiliye-kapak-viralinin-ayrintilari/, 22.10.2009.

[19] Internet World Stats, http://www.internetworldstats.com/euro/tr.htm.

[20] Internet World Stats, http://www.internetworldstats.com/stats4.htm\#europe.

[21] Percentage of internet users in selected countries who watch online video content every day as of January 2017. Statista. The Statistics Portal, https://www.statista.com/statistics/319688/daily-online-video-usage/, 19.09.2017.

\section{Videos}

1. Turkish Airlines: 'Kobe vs. Messi: The Selfie Shootout' https://www.youtube.com/watch?v=jhFqSlvbKAM.

2. Cornetto Turkey: 'Yalın - Keyfi Yolunda, Aşkı Sonunda' https://www.youtube.com/watch?v=xEb87JQ9CKQ.

3. GittiGidiyor.com: 'Fulya'nın Intikamı' https://www.youtube.com/watch?v=O48A8u3aano. 